\title{
Case Comment
}

\section{Renting Space on the Shoulders of Giants: Madey and the Future of the Experimental}

\section{Use Doctrine}

Madey v. Duke University, 307 F.3d 1351 (Fed. Cir. 2002), cert. denied, 123 S. Ct. 2639 (2003).

The experimental use doctrine in patent law protects alleged infringers who use patented inventions solely for experimental purposes, such as testing whether a device functions as claimed or re-creating a process to observe its effects from a scientific perspective. ${ }^{1}$ The judicially created exception traces its lineage back nearly two hundred years. ${ }^{2}$ Although the exception has always been construed narrowly, it grew narrower still in October 2002 when the Federal Circuit issued its opinion in Madey v. Duke University. ${ }^{3}$ Madey reformulated the experimental use doctrine and cast considerable doubt on its continued viability as a defense in patent infringement cases involving universities. As a result, university researchers

1. This Comment discusses the third-party experimental use defense, sometimes called the "research exception." This third-party defense should not be confused with the first-party experimental use defense, which excuses patent owners who have failed to file for patents within one year of using their inventions commercially, as required by 35 U.S.C. $\S 102(b)$, because they have been testing their inventions to be sure they are safe or otherwise ready for patenting. See City of Elizabeth v. Pavement Co., 97 U.S. 126, 134-37 (1877).

2. The experimental use doctrine originated in 1813 with the case of Whittemore v. Cutter, 29 F. Cas. 1120, 1121 (C.C.D. Mass. 1813) (No. 17,600) (Story, J.). By 1861, it was considered "well settled, that an experiment with a patented article for the sole purpose of gratifying a philosophical taste, or curiosity, or for mere amusement, is not an infringement of the rights of the patentee." Poppenhusen v. Falke, 19 F. Cas. 1048, 1049 (C.C.S.D.N.Y. 1861) (No. 11,279).

3. 307 F.3d 1351 (Fed. Cir. 2002), cert. denied, 123 S. Ct. 2639 (2003); see also Jennifer Miller, Sealing the Coffin on the Experimental Use Exception, 2003 DUKE L. \& TECH. REV. 12 (discussing the case and the briefs filed for and against certiorari). 
accustomed to standing on the shoulders of giants by studying patented technologies freely may now be forced to rent space on those shoulders instead. ${ }^{4}$

This Comment argues that the Madey court erred when it characterized university research as driven by a business interest in competing for prestige, students, and research grants. Not only does this view oversimplify experimental use defense by causing it to turn on the status of the defendant rather than the nature of the contested use, but it also undermines the balance between innovation and access that lies at the heart of the Patent Act. The Federal Circuit should have instead crafted a more nuanced experimental use exception that protects educational experimentation on patented inventions. Such a rule might not help Duke in its dispute with Professor Madey, especially if the record on remand confirms that Duke was experimenting with rather than experimenting on Madey's invention, but it would allow future researchers to continue testing and teaching about patented inventions without fear of being sued.

\section{I}

In 1997, Duke University removed physicist John Madey as director of the free electron laser research lab he had founded. Madey resigned from the faculty and eventually sued Duke for patent infringement for continuing to use several pieces of equipment Madey had invented and patented. Duke moved for summary judgment, and the district court held that Madey had failed to demonstrate that Duke, as an educational institution, had a commercial purpose for using the patented equipment. ${ }^{5}$ Madey appealed, and the Federal Circuit reversed and remanded. The Federal Circuit determined that only a "very narrow and strictly limited"6 experimental use exception had survived its previous decisions in Roche Products, Inc. $v$. Bolar Pharmaceutical Co. ${ }^{7}$ and Embrex, Inc. v. Service Engineering Corp. ${ }^{8}$ It characterized the defense as "limited to actions performed 'for amusement, to satisfy idle curiosity, or for strictly philosophical inquiry.","

4. Isaac Newton, in one of the most frequently quoted lines in intellectual property law, reportedly declared, "If I have seen farther, it is by standing on the shoulders of giants." The historical origins of this statement are traced in ROBERT K. MERTON, ON THE SHOULDERS OF GIANTS (1965).

5. See Madey v. Duke Univ., 266 F. Supp. 2d 420, 424-28 (M.D.N.C. 2001), aff d in part and rev'd in part, 307 F.3d 1351, cert. denied, 123 S. Ct. 2639.

6. Madey, 307 F.3d at 1362.

7. 733 F.2d 858 (Fed. Cir. 1984). Congress responded to Roche by creating a limited safe harbor for experimentation by generic drug manufacturers. See Drug Price Competition and Patent Term Restoration Act of 1984, Pub. L. No. 98-417, § 202, 98 Stat. 1585, 1603 (codified as amended at 35 U.S.C. $\$ 271(\mathrm{e})(2000))$.

8. 216 F.3d 1343 (Fed. Cir. 2000).

9. Madey, 307 F.3d at 1362 (quoting Embrex, 216 F.3d at 1349). 
Although the Madey court did not provide any examples of the types of uses that would qualify for the experimental use defense, it delineated the boundaries of the defense by examining what uses would not qualify.

First, the Madey court stated that the experimental use exception should not insulate commercial research from claims of patent infringement. ${ }^{10}$ The court worried that Duke might be using the free electron laser for direct commercial gain by conducting research that might lead to patentable discoveries. As Judge Gajarsa noted, "Duke, ... like other major research institutions of higher learning, is not shy in pursuing an aggressive patent licensing program from which it derives a not insubstantial revenue stream."11

Second, the court expressed concern that use of the laser might unfairly advance Duke's business interests regardless of any resulting commercial applications. Its formulation of what constituted a business interest, however, proved exceedingly broad. The court stated:

[M]ajor research universities, such as Duke, often sanction and fund research projects with arguably no commercial application whatsoever. However, these projects unmistakably further the institution's legitimate business objectives, including educating and enlightening students and faculty participating in these projects. These projects also serve, for example, to increase the status of the institution and lure lucrative research grants, students and faculty. ${ }^{12}$

Under such a broad definition of business interest, it is difficult to conceive of any activity conducted by a university that would count as a "strictly philosophical inquiry" and qualify for the experimental use exception. It is not surprising, then, that press reports about the Madey decision portrayed the case as effectively overturning the experimental use exception, ${ }^{13}$ despite the court's protests to the contrary. ${ }^{14}$

The notion that use of a patent with commercial intent should not be protected by the experimental use doctrine is longstanding. In the same year that Justice Story created the experimental use exception, he held that users

10. Id.

11. Id. at 1363 n.7.

12. Id. at 1362 .

13. See, e.g., Stephen B. Maebius \& Harold C. Wegner, Ruling on Research Exemption Roils Universities, NAT'L L.J., Dec. 16, 2002, at C3 ("[Madey] promises to set off a lively debate about the direction of research at federally funded universities ... and their very right to continue to function as research institutions free from third-party patent problems.").

14. See Madey, 307 F.3d at 1360 ("Our precedent, to which we are bound, continues to recognize the judicially created experimental use defense, however, in a very limited form."). 
with "intent to use for profit" could not avail themselves of the defense. ${ }^{15}$ The Federal Circuit declared more recently in Roche Products that activities conducted under the "guise of scientific inquiry" will not qualify as experimental when they have "definite, cognizable, and not insubstantial commercial purposes." 16

The inability of commercial users to claim experimental use does not imply, however, that activities conducted by noncommercial entities automatically constitute experimental use. The Federal Circuit opinion in Madey expressed concern that the district court had "attached too great a weight to the non-profit educational status of Duke" and had failed to delve into the details of how Duke had been using the microwave guns and the free electron laser covered by two of Madey's patents. ${ }^{17}$ Despite its criticism of the district court, however, the Federal Circuit crafted its own bright-line, status-based rule, making the same mistake as the district court, but in reverse. Instead of formulating an experimental use doctrine capable of looking beyond the identity of the defendant to the nature of the contested use, it effectively precluded all universities from successfully invoking the experimental use defense by characterizing prestige and the formation of a high-quality faculty as "business interests."

The business interest test was initially developed in Pitcairn $v$. United States $^{18}$ to plug a conceptual gap in the commercial-noncommercial distinction. The government, as a noncommercial entity, had sought to exploit the experimental use defense despite acting like an ordinary consumer rather than a researcher. Pitcairn involved a dispute over the use of helicopters containing patented rotor structures and control systems. The United States claimed that it should not be forced to pay a royalty for use of some of the helicopters because they were built to test the lifting ability, flight speed, and range of the equipment. The Court of Claims rebuffed this argument. It noted that the record contained no evidence that the helicopters were built solely for experimental purposes. ${ }^{19}$ It also considered tests and demonstrations to be intended uses of the helicopters and "in keeping with the legitimate business of the using agency." 20 In Pitcairn, the experimentation was fairly clearly linked to the government's interest in using the helicopters for military purposes. The government was not acting out of "curiosity," but instead as a consumer interested in ensuring the helicopters it purchased would meet its needs.

15. Sawin v. Guild, 21 F. Cas. 554, 555 (C.C.D. Mass. 1813) (No. 12,391) (Story, J.).

16. Roche Prods., Inc. v. Bolar Pharm. Co., 733 F.2d 858, 863 (Fed. Cir. 1984) (internal quotation marks omitted).

17. Madey, 307 F.3d at 1362.

18. 547 F.2d 1106 (Ct. Cl. 1976).

19. Id. at 1125 .

20. Id. at 1125-26. 
The same is not true when universities study or teach how a patented device or process works. The mission of universities is to expand the scope of human knowledge. A large component of this mission involves experimenting on inventions to test their limits and understand how they work. Treating activities that advance this mission as furthering a business interest ignores the fact that they simultaneously constitute the type of curiosity-driven inquiries at the heart of the experimental use exception. To say, as the Madey court effectively did, that performing this function precludes institutions of higher education from invoking the experimental use exception allows the tail to wag the dog.

The practical effect of the Madey decision is to draw an artificial line between experiments conducted by individuals and experiments conducted by university researchers. Individual experimenters presumably conduct research for the purposes of "educating and enlightening" themselves and potentially enhancing their "status," yet Madey regards both as business objectives when carried out in a university setting. This distinction without a difference illustrates the shortcomings of basing the experimental use exception on the status of the defendant claiming it, as the Madey court did by adopting such a broad definition of business interest.

The policy considerations underlying both the Patent Act of 1952 and the Copyright Clause itself buttress the view that the Madey court defined business interest too broadly. Patent law establishes a delicate balance between incentivizing new discoveries and stifling innovation by limiting subsequent access to those discoveries. ${ }^{21}$ Exempting core educational activities from liability for infringement helps maintain this balance. Replicating a patented process in the classroom to demonstrate how it works without seeking a license is unlikely to have any discernable commercial impact on the inventor. ${ }^{22}$ Compared to this minimal impact on the incentive to create, allowing experimentation upon patented inventions substantially advances the "Progress of Science and useful Arts.",23

Patent law expects inventors who seek legal protection to disclose their discoveries in exchange for a limited monopoly. ${ }^{24}$ Experimentation and teaching represent integral components of the disclosure process. Allowing a university professor who wants to understand a patented process to study it in the lab and replicate it in a classroom demonstration helps to disseminate the information contained in the patent specification in a more palatable fashion. It also functions as a form of peer review, ensuring that

21. See, e.g., Bonito Boats, Inc. v. Thunder Craft Boats, Inc., 489 U.S. 141, 146 (1989).

22. The lack of a commercial impact depends on respecting the distinction drawn below between experimenting on an invention and experimenting with an invention. See infra Part III.

23. U.S. CONST. art. I, $\S 8$, cl. 8 .

24. See 35 U.S.C. $\S 112$ (2000) (requiring a "written description" and disclosure of the "best mode" of using an invention). 
patent claims are valid and can be replicated. ${ }^{25}$ Moreover, experimentation may uncover additional information about a patented process or device that even the inventor did not fully grasp. ${ }^{26}$ Universities have traditionally played a central role in testing new technologies and publishing findings that inspire subsequent rounds of innovation. Unlike individuals, they can marshal the resources and institutional support necessary to conduct research on the scale required to make scientific breakthroughs. Madey threatens this vital function by categorically denying institutions of higher education the protection of the experimental use exception.

Given the undesirability of a categorical rule either granting universities carte blanche to ignore patents or preventing universities from ever invoking the experimental use defense, the task of crafting a viable experimental use exception remains. Fortunately, the scholarly literature provides substantial guidance on this point. Although scholars disagree on the proper scope of the experimental use exception, two principles frequently guide their analysis: The experimental use exception should only cover noncommercial use of a patented invention, and the exception should protect those who experiment on an invention but not those who experiment with an invention. ${ }^{27}$

Although universities are almost always nonprofit institutions, some university labs resemble commercial enterprises to the extent they seek to patent and profit from their inventions. ${ }^{28}$ Allowing these labs to claim the

25. See Ned A. Israelsen, Making, Using, and Selling Without Infringing: An Examination of 35 U.S.C. Section 271(e) and the Experimental Use Exception to Patent Infringement, 16 AIPLA Q.J. 457, 470 (1989).

26. For example, the Seattle-based company Immunex applied for a patent covering the use of CD40 Ligand, a protein made by helper T-cells, to enhance immune system function. Immunex apparently did not realize that manipulation of CD40 molecules could also help combat drugresistant cancers. That discovery was made by a group of scientists working at Birmingham University in England. See Jon Hunt, Molecule CD40 Can Switch Off Cancer Cells, BIRMINGHAM POST, Mar. 18, 1999, at 6.

27. See Lauren C. Bruzzone, The Research Exemption: A Proposal, 21 AIPLA Q.J. 52, 68-69 (1993) (reviewing the literature and proposing a similar set of guiding principles); see also infra note 33 .

28. The links between universities and industry have grown over time, especially in the patent context. The Bayh-Doyle Act, Pub. L. No. 96-517, §§ 200-211, 94 Stat. 3015, 3019-28 (1980) (codified as amended at 35 U.S.C. $\S \S 200-211$ (2000)), which authorized universities to seek patents on inventions created with public funding, set off an explosion in the number of patents held by institutions of higher education. In 2000 alone, "U.S. universities were awarded 3,272 patents, executed 3,606 licensing agreements, formed 368 startup companies and eamed more than \$1 billion in licensing revenue." Janet Forgrieve, Mining the Technology, ROCKY MTN. NEWS, Apr. 22, 2002, at 1B. The expansion of university patent portfolios has been accompanied by an increase in private funding for academic research, as intended by the Bayh-Doyle Act. From 1980 to 1998 , industry funding grew at an annual rate of $8.1 \%$, reaching $\$ 1.9$ billion in 1997. Robert Miranda, Corporate $U$, MilwaukeE J. SENTINEL, Oct. 15, 2000, at 1J. This 
protection of the experimental use defense based on their connection to nonprofit institutions would give them an unfair advantage in the marketplace. As Suzanne Michel has argued, "[I]t is inequitable to allow an institution to gain from the existence of the patent system without submitting to the restrictions that are necessary for the system to exist in the first place." 29 Accordingly, the traditional prohibition on commercial entities availing themselves of the experimental use exception should be applied in a flexible rather than formalistic manner, to prevent ostensibly nonprofit labs motivated by commercial considerations from abusing the exception. ${ }^{30}$

An appropriate experimental use exception would also recognize that some inventors set out to create tools specifically designed for use in research and teaching. Since professors constitute the normal market for such tools, waiving infringement liability would largely eviscerate the economic incentive to produce research tools in the first place. ${ }^{31}$ As Professor Donald Chisum, author of the leading patent law treatise, once observed while testifying before Congress, "[I]f you had a patent on a microscope and its only use was in research, you wouldn't want to say that anybody could make and sell microscopes, since they are always used for research." $" 32$

One way to solve this dilemma is to distinguish between experimenting with an invention and experimenting on an invention, and to afford protection only to the latter. ${ }^{33}$ When professors experiment with inventions

proliferation of ties between businesses and universities has led one journalist to decry the emergence of an "academic-industrial complex." Richard Louv, Patent-or-Perish Academia Could Cost Us All, SAN DiEgo Union-Trib., Mar. 3, 2002, at A14.

29. Suzanne T. Michel, The Experimental Use Exception to Infringement Applied to Federally Funded Inventions, 7 HIGH TECH. L.J. 369, 400 (1992).

30. Several authors have argued that the most flexible way to police the line between commercial and noncommercial use is to establish a liability rule that prevents a patent owner from obtaining an injunction against experimental uses but allows the owner to seek damages later if the experimentation results in commercial gain. See Rebecca S. Eisenberg, Patents and the Progress of Science: Exclusive Rights and Experimental Use, 56 U. CHI. L. REV. 1017, 1076-77 (1989); Janice M. Mueller, No "Dilettante Affair": Rethinking the Experimental Use Exception to Patent Infringement for Biomedical Research Tools, 76 WASH. L. REV. 1, 9, 54-66 (2001); David L. Parker, Patent Infringement Exemptions for Life Science Research, 16 HouS. J. INT'L L. 615, 659-60 (1994).

31. Scholars occasionally argue that nonmonetary incentives will maintain a healthy supply of scientific breakthroughs in the absence of patent protection. See, e.g., Michel, supra note 29, at 400. As Rebecca Eisenberg has persuasively argued, though, whether science would be advanced more by patent protection or free access is ultimately an empirical question. See Eisenberg, supra note 30 , at 1030 .

32. Transgenic Animal Patent Reform Act of 1989: Hearings Before the Subcomm. on Courts, Intellectual Prop., and the Admin. of Justice of the House Comm. on the Judiciary, 101st Cong. 104 (1989) (statement of Prof. Donald Chisum), quoted in H.R. REP. No. 101-960, at 56 (1990).

33. See Integra Lifesciences I, Ltd. v. Merck KGaA, 331 F.3d 860, 878 n.10 (Fed. Cir. 2003) (Newman, J., dissenting); see also Parker, supra note 30, at 622 n.37 (quoting Ronald D. Hantman, Experimental Use as an Exception to Patent Infringement, 67 J. PAT. \& TRADEMARK 
by using them instrumentally to advance other goals, the risk of upsetting the incentive to innovate is evident. ${ }^{34}$ In contrast, the use of devices and processes as objects of study rather than tools does not present comparable concerns. ${ }^{35}$ Of course, requiring those experimenting on an invention to seek a license could generate some additional revenue for the patent owner, assuming those forced to pay did not respond by foregoing use of the invention altogether. But the marginal effect on incentives to invent would be negligible, since such researchers do not constitute the core market for the invention. ${ }^{36}$ Moreover, this minor impact on the patent owner would be outweighed by the net contribution to the storehouse of knowledge generated when researchers are allowed to supplement the basic disclosure contained in patent applications by conducting additional tests and publishing their findings. ${ }^{37}$

\section{IV}

The Federal Circuit should pull back from its decision in Madey and replace its expansive definition of business interest with a more nuanced experimental use doctrine-one that insulates the core academic functions of universities from lawsuits by protecting noncommercial experimentation on patented inventions. This reformulated experimental use exception would not lead inevitably to a reversal in Madey, since it is simply impossible to say before a more detailed record is developed on remand whether Duke would qualify for the relatively narrow experimental use exception outlined above. Nevertheless, reining in Madey would preserve the important role universities have traditionally played in advancing the progress of science, and allow researchers to stand firmly on the shoulders of giants rather than merely rent space.

-Tom Saunders

OfF. SOC'Y 617, 639 (1985)); id. at 656 ("In England, Germany, and most of Europe, experimentation on a patented invention is covered under the research exemption, while experimentation using a patented invention to achieve other results falls outside the exemption.").

34. See Eisenberg, supra note 30, at 1074.

35. Id. at 1074-75.

36. Professor Robinson, in an influential 1890 treatise, stated that when an invention is used for experimental purposes "the interests of the patentee are not antagonized." 3 WILLIAM C. ROBINSON, THE LAW OF PATENTS FOR USEFUL INVENTIONS $\S 898$ (1890), quoted in Petition for a Writ of Certiorari at 10, Duke Univ. v. Madey, 123 S. Ct. 2639 (2003) (No. 02-1007) (on file with author).

37. See Jordan P. Karp, Note, Experimental Use as Patent Infringement: The Impropriety of a Broad Exception, 100 YALE L.J. 2169, 2180 (1991) ("[N]oncommercial investigations ... do not threaten the potential gains that the patent grant safeguards for the patentee. At the same time, this level of experimental activity is advantageous because it fosters the quest to expand human knowledge."). 